\title{
A national investigation of the correlation between perceptions of human resources management practices and organizational effectiveness
}

\author{
A.J. Templer \\ Business Administration, University of Windsor, Windsor, Canada, N9B 3P4 \\ K.B. Hofmeyr \\ School of Business Leadership, University of South Africa, P.O. Box 392, Pretoria, 0001 Republic of South Africa
}

Accepted 17 June 1988

\begin{abstract}
This study investigates the extent to which organization effectiveness can be predicted from human resources management (HRM) practices. The results are based on data gathered from attitude surveys of a large sample of employees in 38 companies across the USA. It is found that HRM practices can be summarized in six HRM dimensions which predict organization effectiveness at the departmental level, as perceived by employees. Such effectiveness appears to be linked to HRM practices which stress communication, job clarity, management concern, and equity. Opportunities for future research are suggested and implications for management practice are presented.
\end{abstract}

\begin{abstract}
Hierdie studie ondersoek die mate waartoe organisasiedoeltreffendheid voorspel kan word vanuit die toepassing van mannekragbestuurspraktyke. Die resultate word gebaseer op die analise van data bekom van houdingsopnames onder werknemers van 38 maatskappye in die V.S.A. Daar is gevind dat mannekragbestuurspraktyke opgesom kan word in ses dimensies wat organisasiedoeltreffendheid op departementele vlak voorspel, soos waargeneem deur die werknemers. Sulke doeltreffendheid skyn verband te hou met mannekragbestuurspraktyke wat kommunikasie, helderheid van werksvereistes, bestuursbetrokkenheid en gelykheid aksentueer. Moontlike verdere navorsing en implikasies vir bestuurspraktyke word voorgestel.
\end{abstract}

* To whom correspondence should be addressed

Current definitions of Human Resources Management (HRM) (e.g. French, 1986; Milkovich \& Glueck, 1985; Schuler \& Youngblood, 1986) stress the overriding importance of facilitating organization effectiveness. The raison d'etre for HRM is the extent to which its practices contribute to a better organization. The purpose of this study is to investigate whether there is, in actual practice, a link between HRM practices and organizational effectiveness. The particular question to be addressed is whether it is possible to predict organizational effectiveness from the type of HRM practices carried out in organizations.

\section{Changing definitions of HRM and organizational effectiveness}

There has been a change in the definition of the role of HRM and of what is considered to be effective HRM. The change is best summed up as a shift from an emphasis on maintenance and administration to corporate contribution and environmental scanning (e.g. Hunt, 1984; Odiorne, 1984). The conception which emerges is of a HRM function which has 'come of age' by maturing from a low-level welfare department to a corporate-level strategic unit. The change is summarized by Nkomo (1980) as a move through three stages: first, a defensive stage in which personnel acts simply to defend the organization from such things as unions; second, a derived demand stage, in which personnel is tied to reacting to management's demands; and third, a strategic human resource management stage, in which personnel has moved ahead of line management into a pro-active stance requiring initiating and adapting strategies vis-à-vis the environment.

In the recent practitioner literature (e.g. Baird \& Meshoulam, 1986; Holder, 1986; McDonough, 1986; Purcell, 1985; Schneider, 1985) the consensus seems to be that the HRM function is generally gaining more acceptance, particularly as it becomes more integrated with business objectives and faces up to current issues such as improving competitiveness internationally. There are other, more sophisticated models of good personnel practice (e.g. Fombrun, Tichy \& Devanna, 1984; Holman, 1985; Thurley, 1981), but the final picture is similar to that proposed by Nkomo (1980).

It is no easy matter to define what is meant by organizational effectiveness. The literature refers to criteria for evaluating effectiveness ranging from productivity and efficiency considerations to behavioural factors such as morale, organizational flexibility, and job satisfaction (Cunningham, 1977). Kilmann \& Herden (1976) distinguish between internal and external measures of effectiveness and between efficiency and effectiveness, suggesting that the choice of measurement criteria should depend on the focus of the researcher. Steers (1977) provides a reasonable summary of the criteria when he suggests that organizational effectiveness is a function of at least four variables: Organizational characteristics such as structure and technology; environmental characteristics such as economic and market conditions; employee characteristics such as job performance and job attachment; and managerial policies and practices. In 
considering the role of HRM, our particular concern is with the employee and managerial components of effectiveness. While there is further research needed to fully substantiate it, much of the current management literature implies a search for a type of universal excellence. Peters \& Waterman (1982) set the scene in their American study, 'In Search of Excellence', which was followed up by a British study (Goldsmith \& Clutterbuck, 1984) and a Canadian study (Innes, et al. 1986). The principles of effective management extolled sound somewhat similar in all three studies: participation, communication, individual autonomy, commitment, enthusiasm, and strategic human resources planning.

Of particular relevance to HRM is the prominence given to the role of good personnel practices in these profiles of excellence. Effective organizations do have a supportive structure and economic environment of course, but they also seem to have productive employees who believe in the organization, and a HRM function which is closely allied to the fundamental mission of the enterprise and plays a significant role in strategic thinking and business planning. What is not so clear is whether organizational participants actually perceive a link between HRM practices and organizational effectiveness, and how to measure the variables involved.

\section{The HRM audit}

A number of researchers and practitioners have argued for the value of carrying out a personnel or HRM audit (e.g. French, 1982; Milkovich \& Mahoney, 1979; Tsui, 1984; Yoder \& Staudohar, 1982). As defined by Milkovich \& Glueck (1985) the HRM audit is a systematic and formal evaluation of the total personnel programme in the light of the organization's objectives, in much the same way as most organizations carry out systematic and formal financial audits. An important argument is that since labour costs make up the largest single part of nearly all operational budgets, the HRM function should be examined with the same care and concern given to other factors of production. The key objective of the HRM audit is to ensure that the HRM function is contributing to overall organization goals (e.g. Cascio, 1982; Dimick \& Murray, 1978; Milkovich \& Glueck, 1985).

There appear to be two general issues that have to be examined concerning the HRM audit: what areas of HRM practice to include in the audit, and what criteria of organizational effectiveness to employ. Extensive audit checklists have been developed for use by practitioners (e.g. French 1982; Yoder \& Staudohar, 1982), but there has been very little research on the measurement properties of HRM audit instruments. In addition, despite the apparent need for relevant HRM audits there has been little published on the relationship between audit results and outcome criteria such as organizational performance and productivity. From a methodological point of view, an operational definition of effectiveness would best be approached through factor-analytically derived scales which are reliable and in which validity is determined through a regressionbased link to organization effectiveness. This is not often attempted in practice.

An exception is in the study by Gomez-Mejia (1985) which designed and tested a personnel audit instrument in 26 plants of a large US electronics corporation. The nine factors which resulted from the analysis were found to be reliable (Cronbach alpha $>0,70$ ) and to predict executive perceptions of organization effectiveness. The dimensions did also predict actual profitability, but to a lesser extent. The nine dimensions covered were: manpower flows, staffing/EEO, compensation, managerial behaviour, labour relations, health/safety, development, appraisal, and policies/procedures.

The Gomez-Mejia study illustrates the dilemma in the type of criteria to employ. Is it better to use an indirect measure of effectiveness by surveying perceptions of effectiveness? Or is it better to use a direct measure of organizational performance, such as profitability? Employee perceptions are more closely linked to HRM practices, but may be too subjective, and are, of course, not directly linked to organizational success. A direct measure of organizational performance, such as profitability, is a clearly relevant criterion, but is more indirect in its link to HRM practices. Many other factors than HRM influence organization effectiveness and profitability, as noted above in Steers (1977). Support for the use of 'soft' measures is provided in a study by Engel (1977) which indicated that organizational effectiveness can be adequately measured by using the perceptions of employees about how well their units perform. Until further research is completed, it is probably wise not to propose a final answer to this criterion dilemma, but to attempt to replicate GomezMejia's (1985) findings in other settings. In addition, there were some limitations in the Gomez-Mejia study. Firstly, it employed individual and organization-level variables and thus had to make use of a reciprocal averages technique to merge individual and aggregate data. In this process, all individuals from a plant were assigned their respective plant level effectiveness score, at some loss of individual variability.

Secondly, the study was limited in focus to one organization and to the electronic manufacturing industry.

This investigation attempts to build on the GomezMejia study by widening the sample to include a large number of employees in different organizations, and by focusing on just one type of criterion, namely, employee perceptions of organization effectiveness at the departmental level. The research questions which are dealt with are as follows: (a) What are the measurement properties of a HRM audit instrument made up of items reflecting HRM practices?; b) What pattern of HRM practices best predicts organizational effectiveness at the departmental level, as perceived by employees? 


\section{The study}

The study was based on survey data from International Survey Research (ISR), a consulting company based in Chicago and carrying out attitude research in the USA and over 40 other countries. ISR carries out attitude research for client organizations based on replies to a set of common or core items drawn from a larger attitude questionnaire. The large sample size offered a unique research opportunity, but was limited of course by the items in the questionnaire bank which were not specifically designed for the purpose of this study.

\section{Sample}

The sample consisted of 141519 employees drawn from 38 US companies (see Table 1). It can be seen that the sample represents a wide range of industries, but is probably more of a technical/ professional group than the manufacturing sample of Gomez-Mejia (1985). This conclusion is also suggested by the occupational categorization of the sample which was as follows: top Management - 3,5\%; Supervisory - $28,4 \%$; Professional $-23,9 \%$; Technical $-7,7 \%$; Blue Collar $-10,3 \%$; Secretarial/Clerical $-26,2 \%$.

Table 1 Industry-type breakdown of organizations sampled

\begin{tabular}{lccccc}
\hline & \multicolumn{2}{c}{ Total sample } & \multicolumn{2}{c}{ Sub-sample } \\
\cline { 2 - 3 } \cline { 6 - 7 } Industry type & $N$ & $\%$ & & $N$ & $\%$ \\
\hline High Tech: Computers/Electronics & 8 & 21 & & 5 & 29 \\
Insurance & 7 & 18 & & 4 & 23 \\
Financial & 5 & 13 & & 4 & 23 \\
Manufacturing & 4 & 11 & & 1 & 5 \\
Retail & 3 & 8 & & \\
Telecommunications & 3 & 8 & & 1 & 5 \\
Cosmetics/Pharmaceutical & 3 & 8 & & 1 & 5 \\
Transportation & 3 & 8 & & \\
Consumer Electrical & 2 & 5 & & 2 & 10 \\
Total & 38 & 100 & & 18 & 100 \\
\hline
\end{tabular}

The regression analysis was based on 42531 employees drawn from a sub-sample of 18 companies for which complete replies were available. (Incomplete data were not a result of questions left unanswered, but were a function of questions not being asked in some companies.) An investigation was made of the comparability of the larger and smaller groups of organizations by means of a cross-tabulation comparison on nine demographic variables. It was found that employees in the 18 companies were similar to employees in the 38 companies in terms of their tenure, educational level, union membership, and age. But employees in the smaller group tended to be more blue collar (i.e. less management level), and tended to consist of more female and more non-white employees than the larger group. Although the comparability of the two groups may be somewhat less of a problem, given their
Table 2 HRM practice and effectiveness dimensions

\begin{tabular}{|c|c|}
\hline Factor & Loading \\
\hline \multicolumn{2}{|l|}{ Factor 1: Management relations $(\alpha=0,80)$} \\
\hline 1. Management interested in employee well being & 0,70 \\
\hline Little effort to get employees' opinion (reversed) & 0,67 \\
\hline Excellent job of keeping employees informed & 0,62 \\
\hline Employees treated with respect & 0,57 \\
\hline Adequately informed of personnel policies & 0,55 \\
\hline 6. Company promotes most competent people & 0,54 \\
\hline \multicolumn{2}{|l|}{ Factor 2: Role clarity $(\alpha=0,58)$} \\
\hline 7. Training adequate preparation for work & 0,71 \\
\hline $\begin{array}{l}\text { 8. Objectives changed frequently, trouble completing } \\
\text { work (reversed) }\end{array}$ & 0,58 \\
\hline $\begin{array}{l}\text { 9. New employees clearly understand company } \\
\text { expectations }\end{array}$ & 0,57 \\
\hline \multicolumn{2}{|l|}{ Factor 3: Evaluation equity $(\alpha=0,75)$} \\
\hline 10. Evaluation of job performamce understood & 0,71 \\
\hline 11. Job performance is evaluated fairly & 0,71 \\
\hline 12. Compared to others here am paid fairly & 0,43 \\
\hline \multicolumn{2}{|l|}{ Factor 4: Pay and Benefits $(\alpha=0,63)$} \\
\hline 13. Benefits here as good or better than others & 0,77 \\
\hline 14. Benefit programme fits needs & 0,66 \\
\hline 15. Pay here as good or better than others & 0,60 \\
\hline \multicolumn{2}{|l|}{ Factor 5: Work relations $(\alpha=0,60)$} \\
\hline 16. Good cooperation between employees & 0,81 \\
\hline 17. People get along well together & 0,61 \\
\hline 18. Good cooperation between departments & 0,57 \\
\hline \multicolumn{2}{|l|}{ Factor 6: Policy administraticn ( $\alpha=$ single item) } \\
\hline $\begin{array}{l}\text { 19. Personnel policies administered fairly } \\
\text { (Note: This item also loaded } 0,34 \text { on Factor 1) }\end{array}$ & 0,50 \\
\hline \multicolumn{2}{|l|}{ Effectiveness criterion variable $(\alpha=0,70)$} \\
\hline 20. Department operates efficiently & \\
\hline 21. Work in department is well organized & \\
\hline 22. Excellent quality of work in department & \\
\hline
\end{tabular}

relatively large sizes, it was considered advisable to investigate the correlations between the biographical variables and the effectiveness criterion. This was to ensure that the sub-sample used in the regression analysis did not differ substantially from the main sample in effectiveness.

\section{Survey instrument}

The instrument was made up of 22 items (see Table 2) drawn from the 'core' of standard questions used by the research company. Items were presented in a Likert fivepoint scale format ranging from 'agree' to 'disagree'. Items were selected to survey two areas:

\section{Organizational effectiveness}

Three items measuring employee perceptions of organizational effectiveness at the departmental level. These items were summated to form a single effectiveness dimension.

\section{Analysis}

The starting point in the analysis was to identify a set of 
composite HRM audit dimensions that would best integrate the 19 items described above. This was achieved by factor analysing the 19 items using the Principal Components method, with the squared multiple correlation as the estimate of communality. The resulting factors were then rotated using the Varimax procedure, which is the most widely used factoring method (Rummel, 1970). In addition to the factor analysis, the psychometric properties of the dimensions were examined by calculating the Cronbach alpha $(\alpha)$ for the dimensions (Table 2).

Scores on the HRM practices scales defined by the factor analysis were then intercorrelated with the effectiveness dimension to get an initial indication of the direction of the findings (Table 3). The intercorrelations of the biographical variables with the effectiveness dimension were also examined, to determine if any of these biographical variables should be included as dummy variables in the regression analysis. From these correlations it was considered necessary to include race as a predictor in the regression analysis.

The HRM scales and the dummy variable race were then used as predictors in a regression equation against the dependent variable of effectiveness. The procedure used was a hierarchical simultaneous regression in which the HRM variables were entered simultaneously and the dummy variable (race) added in last (see Table 4).

Table 3 Correlations between HRM dimensions and effectiveness

\begin{tabular}{|c|c|c|c|c|c|c|c|c|}
\hline & 1 & 2 & 3 & 4 & 5 & 6 & 7 & 8 \\
\hline 1. Effectiveness & - & & & & & & & \\
\hline 2. Work relations & $\mathbf{0 , 5 1}$ & - & & & & & & \\
\hline 3. Role clarity & 0,39 & 0,33 & - & & & & & \\
\hline 4. Mngt relations & 0,39 & 0,36 & 0,46 & - & & & & \\
\hline 5. Evaluation equity & 0,44 & 0,38 & 0,38 & 0,49 & - & & & \\
\hline 6. Pay and benefits & 0,19 & 0,23 & 0,21 & 0,38 & 0,29 & - & & \\
\hline 7. Policy admin. & 0,30 & 0,31 & 0,43 & 0,46 & 0,33 & 0,28 & - & \\
\hline 8. Race & 0,09 & 0,10 & $-0,05$ & 0,11 & 0,16 & 0,13 & 0,00 & - \\
\hline
\end{tabular}

Table 4 Regression equations between HRM dimensions and effectiveness

\begin{tabular}{lccr}
\hline \multirow{2}{*}{ HRM } & \multicolumn{3}{c}{ Effectiveness } \\
\cline { 2 - 4 } Dimensions & $R$ & $R^{2}$ & Beta \\
\hline Work relations & 0,51 & 0,262 & 0,349 \\
Role clarity & 0,56 & 0,319 & 0,153 \\
Mngt. relations & 0,58 & 0,340 & 0,101 \\
Evaluation equity & 0,61 & 0,366 & 0,191 \\
Pay and benefits & 0,61 & 0,366 & $-0,022$ \\
Policy admin. & 0,61 & 0,367 & 0,026 \\
Dummy var: race & 0,61 & 0,367 & 0,021 \\
\hline
\end{tabular}

Note: All equations significant at $p<0.000$

\section{Reaults}

\section{HRM Practices Dimensions}

A plot of eigenvalues resulting from the factor analysis of the 19 HRM practices items indicated a break at three and six factors. Each of the two solutions was tested by rotating the factor structure to the varimax criterion. On the basis of the rotated factor structure and the interpretation of the factors, the six-factor solution was selected as providing the most complete, interpretable, and parsimonious solution to the analysis. The eigenvalues for all six factors exceeded the standard criterion of 1,0 . The only item not clearly supporting a single factor was the 'fair personnel policy administration' question which loaded on Factor 1 as well as defining Factor 6.

The resulting six factors are shown in Table 2, including those items loading high on each factor. A loading was operationally defined as high or salient if it reached 0,40 or higher. On the average, three items showed salient loadings per factor. Two factors consist of global-type dimensions, namely: factor 1 management relations, which includes management concern and communication; and factor 5-work relations, which is concerned with cooperation and relations between employees. The remaining four factors reflect the operation of various HRM subsystems, training and development (role clarity), performance evaluation, compensation, and personnel policy administration. Table 2 also reports the Cronbach alpha $(\alpha)$ scores for each of the dimensions, except the single item defining factor 6 . Reliability levels average around 0,65 which is sufficient to warrant continuing the analysis, but are generally below the minimum acceptable level of 0,70 required for decision-making purposes. The reliability levels are constrained by the limited number of items per dimension and suggest that the scales would need to be lengthened before using them for decision-making purposes.

Intercorrelations

Correlations were computed between the nine biographical variables and the effectiveness criterion. The correlations of effectiveness with each variable were as follows: $-0,017$; job category: 0,062 ; management functional area: $-0,043$; tenure: $-0,021$; educational level: $-0,024$; union status: $-0,021$; age: $-0,019$; sex: 0,005 ; and race: 0,113 . From these correlations it was decided that only race should be included in the regression analysis. Given the relatively small correlation coefficients, it seemed reasonable to conclude that the biographical differences found between the total sample of 38 companies and the subsample of 18 companies are not likely to be associated with differences in the level of the effectiveness criterion between the two groups.

From Table 3, it can be seen that work relations and evaluation equity have the strongest correlations with the effectiveness criterion. Role clarity and management relations are also clearly associated with effectiveness, but race does not appear to be a significant variable in the relationship between HRM practices and 
organization effectiveness. As was the case in the Gomez-Mejia (1985) study, the table shows that the HRM practices dimensions are intercorrelated.

\section{Prediction of organization effectiveness}

Table 4 shows the results for the regression analysis using the HRM practices dimensions and race to predict organization effectiveness. Given the relatively large sample sizes it is not surprising that all of the dimensions are highly significant against the criterion score. More importantly, the amount of explained variance is reasonably high $(37 \%)$ and compares favourably with the levels found in the Gomez-Mejia (1985) study. While the $R^{2}$ statistic indicates a reasonable goodness of fit of the regression model, there are clearly a number of nonHRM variables which determine organizational effectiveness. The standardized beta coefficients in Table 4 indicate that the work relations dimension has the most significant impact on effectiveness, followed by evaluation equity, role clarity and management relations in descending order of importance. Not surprisingly, this supports the intercorrelations reported in Table 3.

\section{Discussion and Conclusion}

A major purpose of this study was to investigate the measurement properties of a HRM audit instrument. The findings have clearly shown the value of such an instrument and the relative stability of the dimensions identified by Gomez-Mejia (1985). This stability is largely the result of the effort that Gomez-Mejia put into achieving psychometric adequacy in his instrument. The results also indicate that empirical research can identify the HRM dimensions that will consistently predict organizational effectiveness. The instrument used in this study was found to predict perceptions of organizational effectiveness at more or less the same level as the Gomez-Mejia instrument. The amount of variance explained in this study was $37 \%$. In comparison, the Gomez-Mejia study found that HRM practices could explain $22 \%$ of the variance, using the criterion of executive perceptions of overall organization effectiveness. This instrument was found to have predictive validity, in spite of the fact that items, though selected to fit the Gomez-Mejia dimensions, were constrained by the item bank available in the study.

Some conclusions can be drawn on the measurement qualities of the HRM audit instrument used. The items fell into reasonably clear factors, but two of them (management relations and work relations) are rather global in scope. This occurred in the Gomez-Mejia study as well and may be endemic to HRM audit instruments. It may be that the fine distinctions made between different HRM practice areas in the conceptual literature, reflect an academic desire for clear analytical categories, rather than necessarily reflecting actual practice. The results indicate that the reliability coefficient for some of the instrument dimensions is less than ideal, and would probably be improved by a somewhat larger number of items per dimension, and would certainly benefit by the inclusion of items specifically written for the purpose of evaluating HRM.

The results do show that it is possible to predict the effectiveness of an organization from the way in which HRM is carried out. It appears as if the type of organization likely to be judged as effective will be characterized by employees who work well together at both departmental and company level, and have a management team that communicates with them and has a fundamental concern for them. In addition, employees in effective organizations understand how they are evaluated and consider this evaluation to be equitable, and are adequately prepared for their work and have consistent priorities placed upon them. In contrast, it appears as if such variables as the employees' race, their satisfaction with pay and benefits and the way personnel policies are administered in the organization, does not have much impact on perceptions of organization effectiveness.

The picture of the effective organization above has some similarity to that reported in the general studies of 'excellent' organizations (e.g. Peters \& Waterman, 1982). Effective organizations seem to be made up of employees who have a clear role in the organization and work well with each other in achieving that role. This is very much what Peters \& Waterman meant by 'productivity through people'. At first glance, however, these findings seem to differ from those of the GomezMejia (1985) study. That study found that a different set of variables had the strongest link to effectiveness: namely, EEO practices, compensation and rewards, management behaviour, and labour relations. On a closer look at the items with the highest loadings in the areas that best predict organization effectiveness, however, it appears as if some of the same actual HRM practices predict effectiveness in both studies. Thus the key EEO issues that are relevant are fairness and job security; the highest loadings on compensation are fairness items; and some of the most salient items in the management behaviour and labour relations areas concern good employee relations and strike and grievance occurrences. Thus it appears as if organization effectiveness is linked in both studies to issues of communication and job clarity, management concern, and equity.

Although it can be concluded that HRM practices predict perceptions of effectiveness on the part of organization participants, it is not so clear whether these practices predict actual effectiveness. This was also a finding of the Gomez-Mejia study in which only $18 \%$ of the variance was explained when using HRM practices to predict net profit per capita. A limitation of our study is that the effectiveness criterion relates only to the employee and managerial components of the organization effectiveness model of Steers (1977). In addition to HRM, structural, economic, technical, and environmental variables clearly play a critical role in organizational success. Future studies will have to take these additional variables into account before any definitive conclusion can be reached on the impact of HRM on organizational effectiveness. It will also be necessary to consider the interface between the HRM 
function and the other management areas to investigate whether the nature of this interaction makes any difference. It appears to be important that HRM play a significant role in the strategic planning level in the organization, but this was not an issue addressed in this study.

What this study has shown is the important part played by human resource practices in the way employees view their organizations. It can be concluded that it is possible to predict effectiveness from the way human resources are managed, and that this prediction holds across a wide range of organizations and a large number of employees.

\section{References}

Baird, L. \& Meshoulam, I. (1986). A second chance for HR to make the grade. Personnel, vol.4, 45-48.

Cascio, W.F. (1982). Costing human resources: The financial impact of behavior in organizations. Boston: Kent Publishing Company.

Cunningham, J.B. (1977). Approaches to the evaluation of organizational effectiveness. Acad. Manage. Rev., July, $463-474$.

Dimick, D.E. \& Murray, V.V. (1978). Correlates of substantive policy decisions in organizations: The case of human resource management. Acad. Manage. J., vol.21, 611-523.

Engel, J.E. 1977. A study of the relationship between dimensions of worker attitudes and measures of organisational effectiveness. D.B.A. Thesis, Florida State University.

Fombrun, C., Tichy, N.M. \& Devanna, Mary Anne. 1984. Strategic human resource management. New York, NY: John Wiley \& Sons. Inc.

French, W.L. 1982. The personnel management process. Boston: Houghton Mifflin Company.

French, W.L. (1986). Human resources management. Boston, MA: Houghton Mifflin Company.

Goldsmith, W. \& Clutterbuck, D. 1984. The Winning Streak. London, England: George Weidenfeld \& Nicolson, Ltd.

Gomez-Mejia, L.R. 1985. Dimensions and correlates of the personnel audit as an organizational assessment tool. Pers. Psychol., vol. 8, 293-308.

Holder, J. 1986. Regaining the Competitive Edge. Pers. Admin., vol.31, $35 \mathrm{ff}$.
Holman, G. 1985. In search of excellence in personnel management. Pers. Manage., November, 28-30.

Hunt, J.W. 1984. The shifting focus of the personnel function. Pers. Manage., February, 14-19.

Innes, E., Perry, R.L. \& Lyon, J. 1986. The Financial Post Selects the 100 best companies to work for in Canada. Don Mills, Canada: Collins Publishers.

Kilmann, R.H. \& Herden, R.D. 1976. Towards a systemic methodology for evaluating the impact of interventions on organizational effectiveness. Acad. Manage. Rev., July, 87-98.

McDonough, E.F. III. 1988. How Much Power Does HR Have, and What Can It Do to Win More? Pers., January, 18-25.

Milkovich, G.T. \& Glueck, W.F. 1985. Personnel/Human Resource Management: A Diagnostic Approach. 4th Edition. Plano, TX: Business Publications. Inc.

Milkovich, G.T. \& Mahoney, T. 1979. Human resources planning and pair policy. ASPA Handb. Pers. Industr. Rel.. Washington, DC: Bureau of National Affairs. 104-150.

Nkomo, S.M. 1980. Stage three in personnel administration: strategic human resources management. Pers., vol.57, 69-77.

Odiorne, G.S. 1984: Human resource strategies for the nineties. Pers., vol.61, 13-19.

Peters, T.J. \& Waterman, R.H. (Jr.) 1982. In search of excellence. New York: Harper \& Row.

Purcell, J. 1985. Is anybody listening to the corporate personnel department? Pers. Manage., September, 28-31.

Rummel, R.J. 1970. Applied factor analysis. Evanston: Northwestern University Press.

Schneider, W.E. 1985. The paradigm shift in human resources. Pers. J., November, vol.67, 14-21.

Schuler, R.S. \& Youngblood, S.A. 1986. Effective personnel management, 2nd Edition. St. Paul, MN: West Publishing Company.

Steers, R.M. 1977. Organizational Effectiveness: A behavioral view. Glenview, IL: Scott, Foresman and Company.

Thurley, K. 1981. Personnel Management in the UK - A case for urgent treatment? Pers. Manage., vol.13, 24-29.

Tsui, A.S. (1984). Personnel department effectiveness: A tripartite approach. Industr. Rel., 23, 184-198.

Yoder, O. \& Staudohar, P.D. (1982). Personnel management and industrial relations. New Jersey: Prentice Hall, Inc. 